\title{
KARST AQUIFER AVERAGE CATCHMENT AREA ASSESSMENT THROUGH MONTHLY WATER BALANCE EQUATION WITH LIMITED METEOROLOGICAL DATA SET: APPLICATION TO GRZA SPRING IN EASTERN SERBIA
}

\author{
OCENA POVPREČNEGA PRISPEVNEGA ZALEDJA V KRAŠKEM \\ VODONOSNIKU Z ENAČBO MESEČNE VODNE BILANCE Z \\ OMEJENIMI METEOROLOŠKIMI PODATKI: UPORABA NA PRIMERU \\ IZVIRA GRZA V VZHODNI SRBIJI
}

\author{
Vesna Ristić VAKANJAC ${ }^{1}$, Stevan PROHASKA², Dušan POLOMČIĆ ${ }^{3}$, Borislava BLAGOJEVIĆ ${ }^{4}$ \\ \& Boris VAKANJAC 5
}

\begin{abstract}
UDC 556.33:551.44(497.11)

Vesna Ristić Vakanjac, Stevan Prohaska, Dušan Polomčić, Borislava Blagojević \& Boris Vakanjac: Karst aquifer average catchment area assessment through monthly water balance equation with limited meteorological data set: Application to Grza spring in Eastern Serbia

In the absence of detailed exploration of karstic catchments, the calculation of available reserves and elements of the water balance equation frequently reflect the topographic size of the catchment area, and not the actual, active (underground) size. The two differ largely where karst is concerned. The paper deals with the problem of average catchment area size estimation in the situation when meteorological data are limited to precipitation and temperature, but discharge records are available for long period. Proposed methodology was applied to, calibrated, and validated on 15 karst springs in Serbia. Results obtained with the model differ up to $20 \%$ from hydrogeological exploration results. One of investigated springs is Grza karst spring, which belongs to the karstic formation of Kučaj and Beljanica (the Carpatho-Balkanide Arch of Eastern Serbia). In this paper, we used the Grza Spring to show model application and necessary improvements to progress from graphoanalytical to analytical model. The average catchment area is linked to the model parameter that reduces potential to real evapotranspiration on monthly bases. The model potential lies in the possibility to determine not only catchment area, but real evapotranspiration and dynamic volume of the porous - karst groundwater storage as well.
\end{abstract}

Key words: karst, groundwater, catchment area, water balance, graphoanalytical method.
Povzetek

UDK 556.33:551.44(497.11)

Vesna Ristić Vakanjac, Stevan Prohaska, Dušan Polomčić, Borislava Blagojević \& Boris Vakanjac: Ocena povprečnega prispevnega zaledja $v$ kraškem vodonosniku $z$ enačbo mesečne vodne bilance z omejenimi meteorološkimi podatki: Uporaba na primeru izvira Grza v vzhodni Srbiji

Ob pomanjkanju podrobnih raziskav kraških prispevnih zaledij, se ob izračunih razpoložljivih zalog podtalnice in elementov enačbe vodne bilance, pogosto odraža topografska velikost prispevne površine, in ne dejanska, aktivna (podzemne) velikost vodonosnika. V primeru krasa se te ocene lahko zelo razlikujejo. Prispevek se ukvarja s problemom izračuna povprečne velikosti prispevnega zaledja v razmerah, ko so meteorološki podatki omejeni na padavine in temperature, in ko so podatki o pretokih razpoložljivi za daljše obdobje. Predlagana metodologija je bila uporabljena, popravljena in preizkušena na 15 izvirih v Srbiji. Rezultati dobljeni z modelom se razlikujejo od hidrogeoloških raziskovalnih rezultatov za $20 \%$. Eden od proučevanih izvirov je izvir Grza, ki izvira iz kraških formacij Kučaj in Beljanica (Karpato-Balkanski lok vzhodne Srbije). V tem prispevku smo na primeru izvira Grza prikazali aplikacijo modela in potrebne izboljšave za napredek iz grafoanalitičnega $\mathrm{v}$ analitičen model. Povprečna velikost prispevnega zaledja je povezana s parametrom modela, ki zmanjšuje potencial dejanske evapotranspiracije na mesečni osnovi. $\mathrm{Z}$ modelom lahko ocenimo tako velikost prispevnega zaledja, kot tudi dejansko evapotranspiracijo in dinamično prostornino skladiščenja podzemne vode.

Ključne besede: kras, podtalnica, prispevno zaledje, vodna bilanca, grafoanalitična metoda.

${ }^{1}$ University of Belgrade, Faculty of Mining and Geology, 11000 Belgrade, Djušina Street 7, Serbia, e-mail: vesna_ristic2002@yahoo.com

${ }^{2}$ Institute for the development of water resources "Jaroslav Černi” 11226 Belgrade, Jaroslava Černog street 80, Serbia, e-mail: Stevan.Prohaska@jcerni.co.rs

${ }^{3}$ University of Belgrade, Faculty of Mining and Geology, 11000 Belgrade, Djušina Street 7, Serbia, e-mail: dupol2@gmail.com, tel. +381-11-3219-235 (Corresponding author)

${ }^{4}$ University of Niš, Faculty of Civil Engineering and Architecture, 18000 Niš, Aleksandra Medvedeva 14, Serbia, e-mail: borislava.blagojevic@gaf.ni.ac.rs

${ }^{5}$ University Singidunum, Futura Faculty of Applied Ecology, 11000 Belgrade, Lazarevački drum 13-15, Serbia, e-mail: borivac@gmail.com

Received/Prejeto: 18.01.2012 


\section{INTRODUCTION}

Water resources in karst terrains are becoming increasingly important source for drinking water supply. In terms of quality these are high category waters, thus treatment costs are low. This is due to the ability of karst massif to accumulate certain amount of water and subsequently discharge through karst springs (White 2002). In most cases, karst massifs are forming significant dynamic and static water reserves, available for water supply during long dry periods (Bakalowicz 2005; Ford \& Williams 2007). These reserves are usualy estimated from water balance equation where karstic catchment area plays an important role. Poorly defined catchment area poses a problem in karst aquifer water balacing and direct result is miscalculation of water balance elements (Bonacci 1999; Bonacci et al., 2006). Additional problem is variable catchment area during dry and wet years (Ford \& Williams 2007, Ravbar et al. 2011), as well as groundwater piracy and bifurcation in the karst (Goldscheider et al. 2008). For these reasons, detailed and costly hydrogeological explorations are required to define size of catchment area as realistically as possible.

In the situation when exploration data are limited, hydrological approach is the only option. Groundwater hydrograph method (Bonacci 1987) is one of the hydrologic approach representatives. The method uses the minimization of difference between simulated and observed hydrographs by varying the catchment area size. Other methods include empirical expressions for runoff deficit calculations and regional formulae (Bonacci 1987, 1999; Bonacci \& Magdalenić 1993), or regional precipitation and evapotranspiration maps (Petrič 2002).

Methodology explained in section 2 of this paper is based on water balance and it uses the minimization of difference between initial and final water volume of karstic spring aquifer by varying the catchment area size. Methodology is explained in more detail in comparison to the prior publication (Stevanović et al. 2010), and case study is shown in the third and fourth part. The paper aim is the revision of previous approach. Therefore, Section 5 is dedicated to the discussion of achieved results and description of methodology weaknesses, which ends up in the form of Conclusion with directions for necessary additional research.

\section{METHODOLOGY}

If the karstic formation is viewed as a system which transforms incoming precipitation into karst spring discharge, then the input into the system can be represented by precipitation which reaches the entire catchment area of the karst spring (Fiorillo \& Doglioni 2010). Therefore, we use model for karst aquifer catchment area assessment based on general water balance equation in monthly time steps:

$$
P_{i j}=h_{i j}+E_{i j}+\left(V_{i j}-V_{i, j-1}\right)=h_{i j}+E_{i j} \pm \Delta_{i j}
$$

where $P_{i j}$ is precipitation total $[\mathrm{mm}] ; h_{i j}$ is spring discharge mean $[\mathrm{mm}] ; E_{i j}$ is the total real evapotranspiration (RET) $[\mathrm{mm}] ; V_{i j}$ is the volume of water $[\mathrm{mm}]$ in the analyzed karst aquifer during the $j^{\text {th }}$ month; and $D_{i j}$ is the change in water reserves in the karstic formation during the $j^{\text {th }}$ month of the $i^{\text {th }}$ year $[\mathrm{mm}]$. For this form of equation (1), $h_{i j}$ is directly dependent on karst aquifer catchment area $F\left[\mathrm{~km}^{2}\right]$. This defines spatial condition for water balance application. In order to satisfy temporal condition, we use cyclicity of spring discharge process to define reference period in which the initial and final volume of water in the analyzed karst aquifer are approximately the same:

$$
\mathrm{V}_{0} \cong \mathrm{V}_{\mathrm{K}}
$$

where 0 and $\mathrm{K}$ stand for the beginning and end of the reference period, respectively.

Water formation process in the karstic massif is stochastic in nature. This means that there is a certain stochastic rule of alternating rainy (wet) and dry periods, as well as years. For reliable estimation of water balance elements at least one full discharge cycle is required. A cycle includes one dry period and one wet period. As a cycle indicator, we use the following form of cumulative standardized mean annual discharge $\left(Q_{i}\left[\mathrm{~m}^{3} / \mathrm{s}\right]\right)$ :

$$
Z(t)=\sum_{i=1}^{t} \frac{Q_{j}-Q_{\text {mean }}}{s_{Q}}=\sum_{i=1}^{t} z_{i}
$$

where: $\mathrm{z}_{\mathrm{i}}$ is standardized variable; $Q_{i}$ is mean annual discharge $\left[\mathrm{m}^{3} / \mathrm{s}\right] ; Q_{\text {mean }}$ is mean discharge in the studied period $\left[\mathrm{m}^{3} / \mathrm{s}\right]$; and $s_{Q}$ is standard deviation of the mean annual discharge series $\left[\mathrm{m}^{3} / \mathrm{s}\right]$. 
When $Z(t)(3)$ is plotted as a function of time $(t)$, negative $\mathrm{z}$ values produce downward tendencies indicating presence of dry years, while positive (upward tendencies) indicate presence of wet years. The $Z(t)$ plot assists with the selection of the reference period.

In the absence of full meteorological variables data set in the reference period, we estimate daily RET assuming its nonlinear distribution after the day with precipitation:

$$
E_{i j(k+\tau)}=\Theta^{2 \tau} \cdot P E T_{i j k}
$$

where: $t=0,1,2,3 \ldots, \mathrm{m}$ represent days following each rainy day $(\tau=0) ; \Theta$ is model parameter $(0<\Theta<1)$. We obtain daily PET using slightly modified Thornthwait method (Thornthwait 1948):

$$
P E T_{i j k}=\frac{0.4 \cdot N_{i j}}{3}\left(\frac{10 \cdot T_{i j k}}{I_{i}}\right)^{\alpha}
$$

where $N_{i j}$ is the total monthly insolation [h]; $T_{i j k}$ is the average daily temperature $\left[{ }^{\circ} \mathrm{C}\right]$ of the $k^{\text {th }}$ day; $I_{i}$ the annual heat index; and $\alpha$ is a function of the annual heat index. The annual heat index is obtained using average monthly temperatures, from the following equation:

$$
I_{i}=\sum_{j=1}^{12}\left(\frac{T_{i j}}{5}\right)^{1.514}
$$

and parameter $\alpha$ is obtained from the polynomial function:

$$
\alpha=6.15 \cdot 10^{-7} \cdot I_{i}^{3}-7.71 \cdot 10^{-5} \cdot I_{i}^{2}+1.789 \cdot 10^{-2} \cdot I_{i}+0.49
$$

We summarize daily RET in each month of the reference period to estimate $E_{i j}$, for different values of model parameter $\Theta$ and calculate spring discharge monthly mean $\left(\mathrm{Q}_{\mathrm{ij}}\right)$ from daily mean discharge record $\left(Q_{i j k}\right)$. Than, we start volume calculation from water balance equation (1) for the reference period in monthly time steps for each value of model parameter $\Theta$ in the form:

$$
V_{i j}=P_{i j}-h_{i j}-E_{i j}+V i_{j-1}
$$

where $E_{i j}$ is a function of $\Theta$, and $h_{i j}$ of F. For each $\Theta$ we gradually approach the solution of equation (1) by varying value of $F$, until boundary condition (2) is satisfied. The goal of this optimizing procedure is to obtain graphical form of the relation $\Theta=f(F)$, represented by thick solid line on Fig.1.

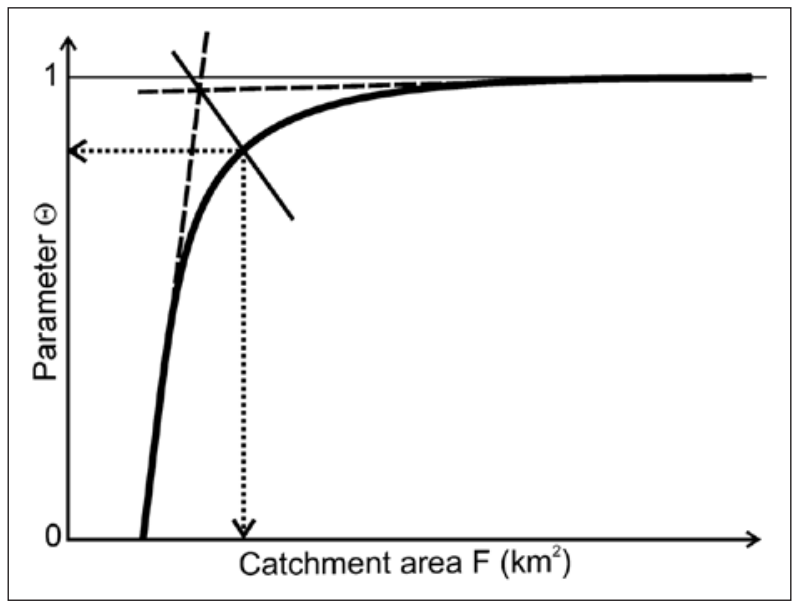

Fig. 1: Obtaining actual catchment area by constructing $\Theta=f(F)$ (curved solid line), linear extensions to the ends of $\Theta=f(F)-$ dashed lines, and extensions' crossing angle median (straight solid line).

We obtain the actual catchment area by extending linear tendency at extreme sections of the plot $\Theta=f(F)$ (dashed lines on Fig .1), constructing crossing angle median (straight solid line on Fig.1) and finding crossing point $(\Theta, F)$ of angle median and dependence $\Theta=f(F)$. While $\mathrm{F}$ is average catchment area sought, $\Theta$ is the optimal model parameter value. With this value, we recalculate water balance and obtain its real components.

With real components of water balance we estimate the dynamic volume $(\Delta V)$ as the difference between the maximum $\left(V_{\max }\right)$ and minimum $\left(V_{\min }\right)$ volume of water in the karst aquifer in the reference period:

$$
\Delta V=V_{\max }-V_{\min }
$$

\section{STUDY AREA AND INPUT DATA}

\section{HYDROGEOLOGICAL PROPERTIES AND DESCRIPTION OF THE GRZA SPRING CATCHMENT AREA}

The Grza Spring drains parts of the Kučaj karstic massif (Carpatho-Balkanide Arch) (Fig. 2).
The catchment area of the Grza Spring generally consists of a carbonate rock formation, with occasional fissured rocks (Cvijić 1895). There are several semipervious parts of the terrain, which constitute a virtual barrier for karst groundwater flow (Stevanović 1991) (Fig. 3). 


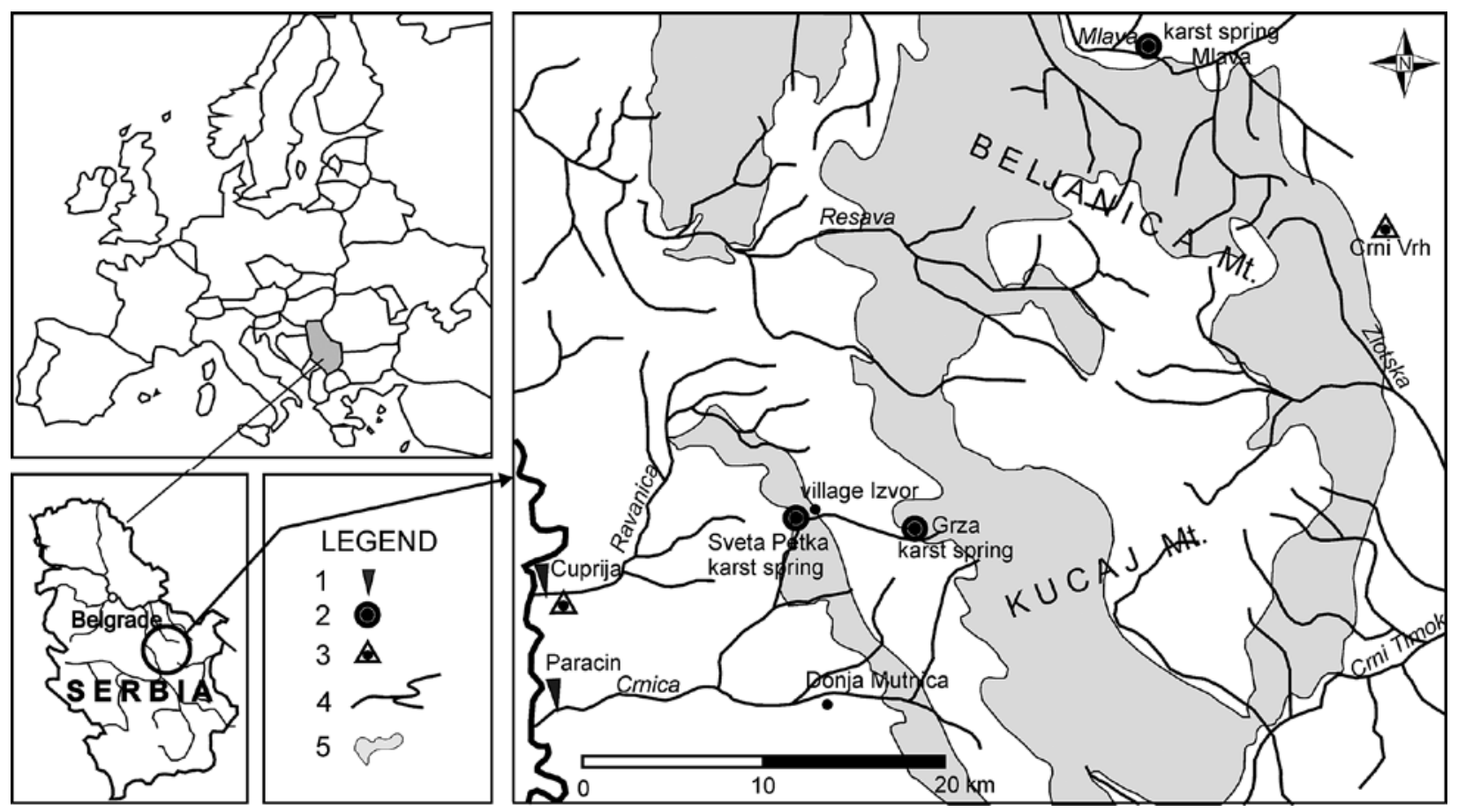

Fig. 2: Geographical location of the karst spring Grza.

Legend: 1. Hydrological station, 2. Raingauge, 3. Weather station, 4. Rivers and streams, 5. Karst terrain

The Grza Spring drains a large portion of the Bele Vode karstic plain. Its elevation is $420 \mathrm{~m}$. The location of the spring is the lowest hypsometric point of the area, where limestones appear on the ground surface (this location is the lowest point of contact between the karst and non-karst) (Djurović 1998; Krešić 1988). The higest point in the surface catchment area is $1049 \mathrm{~m}$. The spring is connected to an Urgonian limestone/Permian sandstone interface and constitutes a cluster of groundwater sources (Marković 1954). This is a gravity type spring and the source zone displaces vertically by as much as 5 $\mathrm{m}$, depending on the groundwater level in the karst aquifer. The left arm of the source emerges at the bottom of a short karstified dale, with large limestone blocks in the riverbed. The right arm is formed from cavernous channels and in lower level is in developed limestone blocks that mask the primary source (Fig 4). During high-water events, colour tracer tests have shown a link between the Velika Brezovica sinkhole and the Grza Spring (Dragišić et al. 1990) (Fig. 3).

Fig. 5 is selected to show three specific annual extreme discharges that occure at Grza spring. The first maxima occures in March-April due to snowmelt. The second one in the period of intensive spring and early summer rains, while the third, least intensive, in December due to winter precipitation. There are two distinct minima. The first occures in the discharge recession pe- riod lasting up to 120 days (August - November), and the second in winter months (December-February) due to low temperatures at high altetudes that contributes to detention of ice and snow. The minimum discharge of the spring is $15 \mathrm{l} / \mathrm{s}$, but it can increase to as much as $2000 \mathrm{l} / \mathrm{s}$ or more $\left(9.4 \mathrm{~m}^{3} / \mathrm{s}\right.$ observed on May 9 th 1989 , see Fig. 5). The spring has not been captured.

\section{INPUT DATA}

There were two available sources of input data: 1) Official raingauge and weather station records from Hydro-meteorological Service of Republic of Serbia, and 2) Discharge records from the Public Utility Company of Paraćin from the year 1961 to 2000 .

Based on discharge records for Grza spring, mean annual discharge is calculated, standardized, and cumulative standardized mean annual discharge plotted (3). From the $\mathrm{Z}(\mathrm{t})$ plot shown on Fig. 6 we conclude that period under consideration indicates one full cycle: the end of dry years in the previous cycle (1961-1965), the entire wet phase of the next cycle (1966-1986) and the initial dry phase of the next cycle (1987-2000). Therefore, we consider 1961-2000 to be the reference period for water balancing of Grza spring catchment area.

Locations of raingauge and weather stations in the vicinity of Grza spring are shown in Fig. 2. Although sited $40 \mathrm{~km}$ to the Northeast from Grza spring, weather 


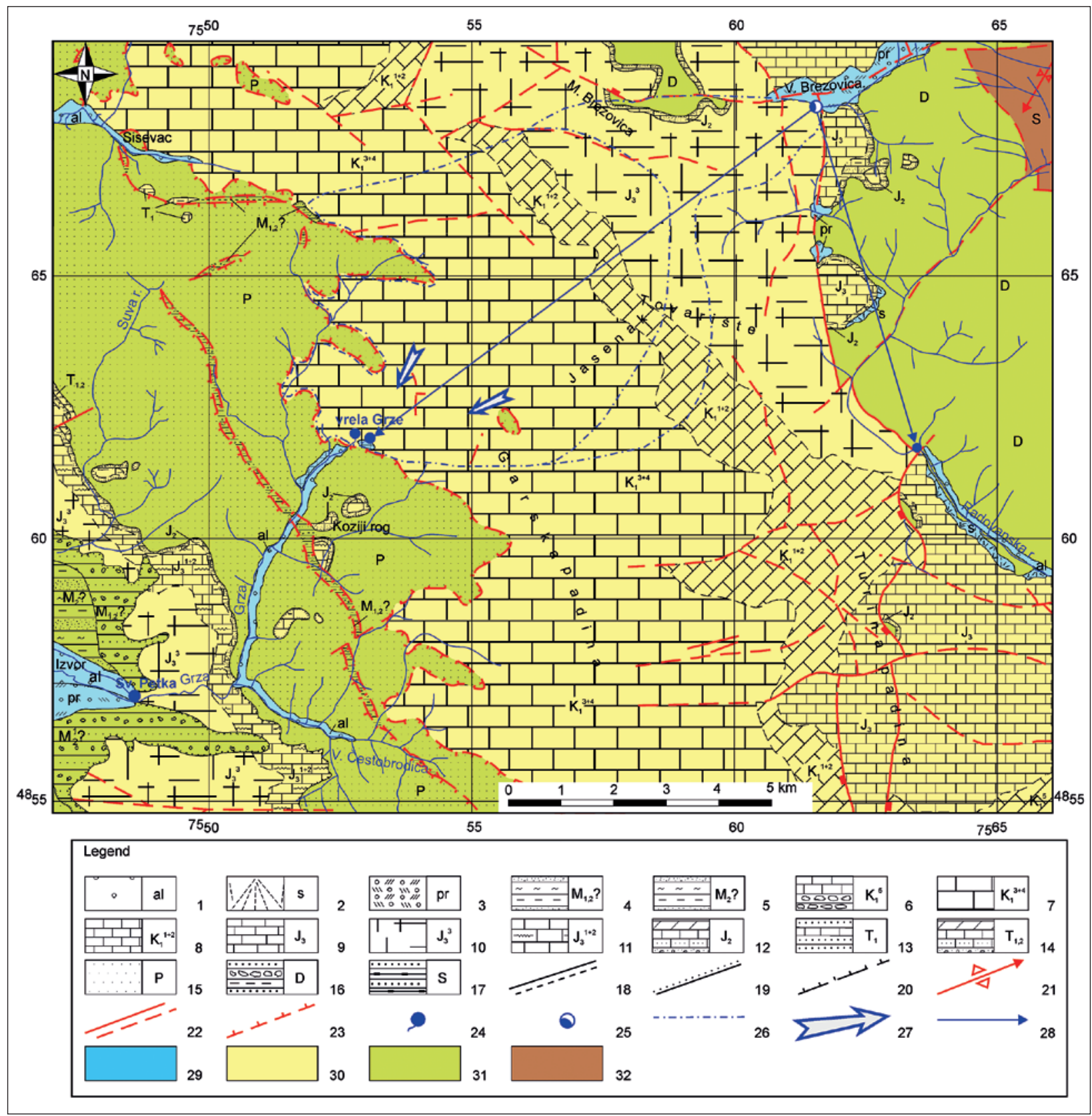

Fig. 3: Hydrogeological map of the Grza Spring vicinity (Ristic 2007). Legend: 1. Alluvium, 2. Talus, 3. Proluvial deposit, 4. Marl, 5. Marl, 6. Limestone and conglomerate, 7. Massive and thick-bedded limestone, 8. Bedding limestone, 9. Limestone and dolomitic limestone, 10. Massive and reeflimestone, 11. Limestone with chert, 12. Clastites and limestone, 13. Sandstone and limestone, 14. Sandstone, limestone and marl, 15. Red Permian sandstone, 16. Sandstone, silt and conglomerate, 17. Sandstone, lydite and argilloschist, 18. Normal geological boundary, 19. Tectonic-erozion boundary, 20. Magmatic body boundary, 21. Sinking anticline axis 22. Fault, 23. Front of thrust, 24. Spring, 25. Sinkhole, 26. Underground watershed, 27. Aquifer flow direction, determined, 28. Connection between sinkhole and karst spring, determined, 29. Unconfined/alluvial aquifer, 30. Karst aquifer, 31. Fracture aquifer, 32. Area without aquifers.

station Crni Vrh has been included in research because of being the closest station which reflects the precipitation and temperature regime at altitudes higher than $500 \mathrm{~m}$, thus corresponding to hypsometric situation in the studied catchment.
Table 1 shows the degree of dependence of mean annual discharge from annual precipitation sum, and mean monthly discharge from monthly precipitation sum, measured by Pearson's correlation coefficient for 

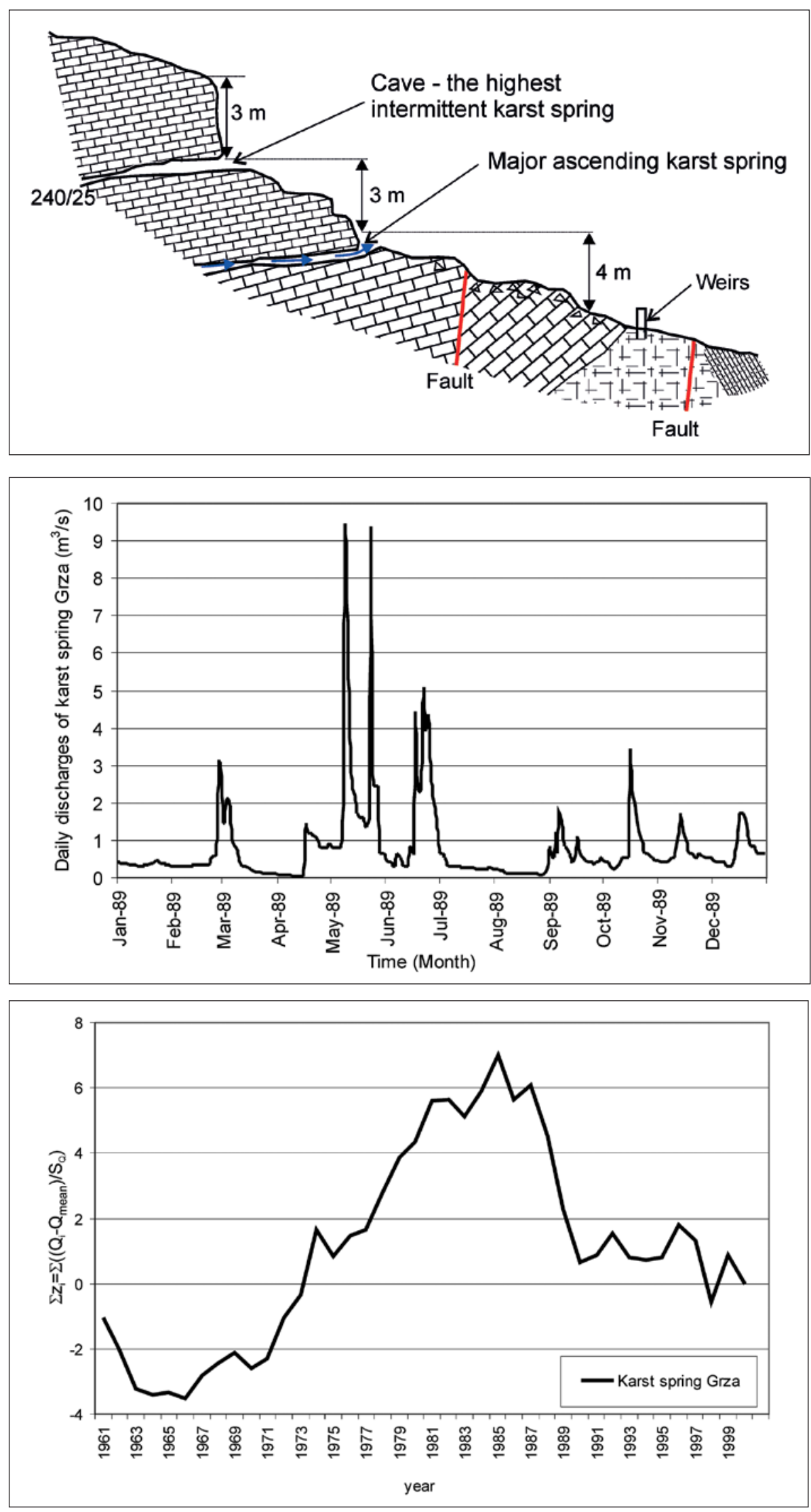

Fig. 4 Cross-sectional sketch of the Grza Spring (Milojević, 1975)

Fig. 5 Hydrograph of karst spring Grza for 1989 year
Fig. 6: Cumulative standardized mean annual discharge plot $Z(t)$ for the spring of Grza. 
Table 1: Coefficients of correlation ( $r$ ) between precipitation and discharge data series, and standard error of estimate for correlation coefficients $\left(S_{r}\right)$.

\begin{tabular}{l|c|c|c|c}
\hline \multirow{2}{*}{$\begin{array}{l}\text { Raingauge/weather station } \\
\text { (altitude) }\end{array}$} & \multicolumn{2}{|c|}{ Annual data series } & \multicolumn{2}{c}{ Monthly data series } \\
\cline { 2 - 5 } & $r$ & $S_{r}$ & $r$ & $S_{r}$ \\
\hline Donja Mutnica (230 m.a.s.I.) & 0.502 & 0.14 & 0.326 & 0.04 \\
\hline Izvor (230 m.a.s.I.) & 0.462 & 0.14 & 0.343 & 0.04 \\
\hline Crni Vrh (1027 m.a.s.I.) & 0.385 & 0.15 & 0.287 & 0.04 \\
\hline Ćuprija (123 m.a.s.I.) & 0.579 & 0.13 & 0.315 & 0.04 \\
\hline
\end{tabular}

Grza spring discharges and precipitation gauged at four stations.

Notwithstanding the results shown in Table 1, we used Crni Vrh precipitation data as input data for the

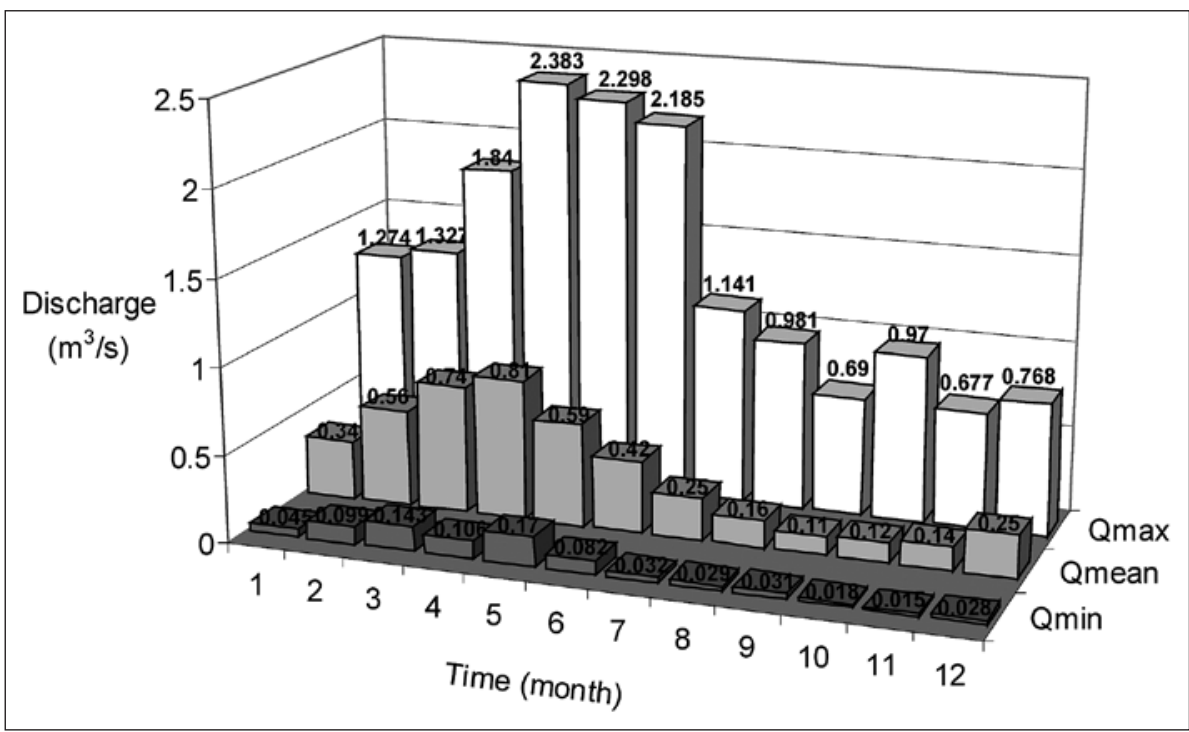

model. Grza catchment altitude ranges from 420 to 1049 m, while Cuprija altitude is $123 \mathrm{~m}$, and Crni Vrh is at $1027 \mathrm{~m}$. Mean air temperature in Cuprija for the reference period was $11^{\circ} \mathrm{C}$, while it was $8.7^{\circ} \mathrm{C}$ at $\mathrm{Crni}$ Vrh. We do not differentiate precipitation between rain and snow, because available records did not provide the distinction.

Fig. 7 shows discharge distribution chart by maximum, mean and minimum monthly discharges for the 1961-2000 period. Mean discharge for the reference period is $0.374 \mathrm{~m}^{3} / \mathrm{s}$.

Fig. 7: Characteristic monthly discharges of the Grza Spring during the 1961-2000 period (m3/s).

\section{RESULTS}

GRZA SPRING CATCHMENT AREA

For each of the model parameter values $\Theta=0.01,0.1$, $0.2, \ldots, 0.8,0.9,0.95$ and 0.99 , we calibrated potential catchment area in equation (8) for each month in the reference period at once, with respect to boundary condition (2), and obtained plot $\Theta=f(F)$ (Fig. 8). We estimated Grza spring actual catchment area to $37.8 \mathrm{~km}^{2}$, and found optimal value of model parameter $\Theta=0.87$.

\section{WATER BALANCE ELEMENTS}

Annual values of the main hydro-meteorological parameters for Grza spring are shown in Table 2 for the reference period. Precipitation totals and mean discharges were observed, while evapotranspiration annual totals are calculated based on optimal value of model parameter $\Theta$.

Table 3 shows water balance elements and other characteristics of interest, obtained for the reference period based on optimal value of model parameter Q $=0.87$, and for two naighbouring values: $\mathrm{Q}=0.86$ and 0.88 . These elements are: mean annual precipitation total $\mathrm{P}[\mathrm{mm}]$, mean annual evapotranspiration total $\mathrm{E}[\mathrm{mm}]$, mean discharge estimated with respect to catchment area $h[\mathrm{~mm}]$ and observed $Q_{\text {mean }}\left[\mathrm{m}^{3} / \mathrm{s}\right]$, achieved water balance estimation accuracy in the form of volume difference (2) both in $[\mathrm{mm}]$ and $\left[10^{6} \mathrm{~m}^{3}\right]$, mean discharge yield $\mathrm{q}\left[\mathrm{l} / \mathrm{s} / \mathrm{km}^{2}\right]$, discharge volume $\mathrm{W}\left[10^{6} \mathrm{~m}^{3}\right]$, and discharge coefficient $j(j=h / P)$. 


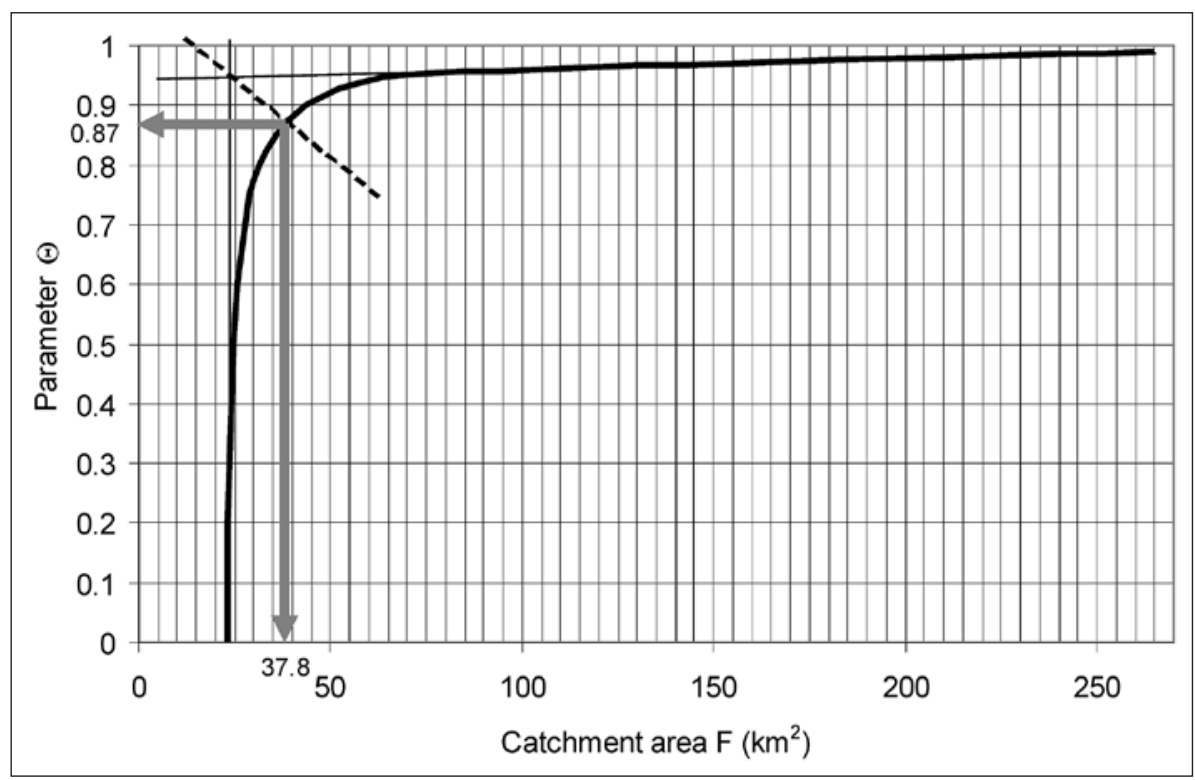

Fig. 8: Estimates of actual catchment area (F) and optimal model parameter (Q) value for Grza spring from $Q=f(F)$.

Table 2. Observed precipitation totals (Crni Vrh) and mean discharges (Grza spring), and estimated evapotranspiration totals from the model in the reference period shown by year.

\begin{tabular}{|c|c|c|c|c|c|c|c|c|c|c|c|}
\hline Year & $\begin{array}{c}P \\
{[\mathrm{~mm}]}\end{array}$ & $\begin{array}{c}E \\
{[\mathrm{~mm}]}\end{array}$ & $\begin{array}{c}Q \\
{\left[\mathrm{~m}^{3} / \mathrm{s}\right]}\end{array}$ & Year & $\begin{array}{c}P \\
{[\mathrm{~mm}]}\end{array}$ & $\begin{array}{c}E \\
{[\mathrm{~mm}]}\end{array}$ & $\begin{array}{c}Q \\
{\left[\mathrm{~m}^{3} / \mathrm{s}\right]}\end{array}$ & Year & $\begin{array}{c}P \\
{[\mathrm{~mm}]}\end{array}$ & $\begin{array}{c}E \\
{[\mathrm{~mm}]}\end{array}$ & $\begin{array}{c}Q \\
{\left[\mathrm{~m}^{3} / \mathrm{s}\right]}\end{array}$ \\
\hline 1961 & 581 & 344 & 0.300 & 1975 & 816 & 559 & 0.396 & 1989 & 799 & 323 & 0.780 \\
\hline 1962 & 661 & 321 & 0.503 & 1976 & 730 & 388 & 0.396 & 1990 & 497 & 257 & 0.385 \\
\hline 1963 & 735 & 427 & 0.307 & 1977 & 803 & 472 & 0.434 & 1991 & 655 & 334 & 0.326 \\
\hline 1964 & 650 & 437 & 0.326 & 1978 & 676 & 358 & 0.316 & 1992 & 669 & 330 & 0.295 \\
\hline 1965 & 656 & 365 & 0.366 & 1979 & 874 & 421 & 0.235 & 1993 & 464 & 420 & 0.238 \\
\hline 1966 & 660 & 535 & 0.385 & 1980 & 1013 & 474 & 0.511 & 1994 & 615 & 480 & 0.223 \\
\hline 1967 & 639 & 331 & 0.287 & 1981 & 775 & 408 & 0.253 & 1995 & 742 & 458 & 0.350 \\
\hline 1968 & 531 & 467 & 0.304 & 1982 & 556 & 382 & 0.245 & 1996 & 817 & 353 & 0.424 \\
\hline 1969 & 776 & 447 & 0.480 & 1983 & 573 & 450 & 0.215 & 1997 & 768 & 423 & 0.469 \\
\hline 1970 & 1003 & 482 & 0.613 & 1984 & 589 & 369 & 0.167 & 1998 & 736 & 443 & 0.631 \\
\hline 1971 & 638 & 444 & 0.326 & 1985 & 815 & 429 & 0.298 & 1999 & 1047 & 395 & 0.427 \\
\hline 1972 & 827 & 471 & 0.327 & 1986 & 648 & 361 & 0.441 & 2000 & 504 & 295 & 0.342 \\
\hline 1973 & 562 & 402 & 0.259 & 1987 & 691 & 220 & 0.438 & \multirow{2}{*}{ mean } & \multirow{2}{*}{710} & \multirow{2}{*}{400} & \multirow{2}{*}{0.374} \\
\hline 1974 & 968 & 399 & 0.410 & 1988 & 647 & 319 & 0.537 & & & & \\
\hline
\end{tabular}

Table 3: Water balance elements for Grza spring in the period 1961-2000. Adopted elements obtained for $Q=0.87$ are given in bold type.

\begin{tabular}{|c|c|c|c|c|c|c|c|c|c|c|}
\hline$Q$ & $F$ & $P$ & $E$ & $h$ & & & Qmean & $q$ & $w$ & $j$ \\
\hline$[-]$ & {$\left[\mathrm{km}^{2}\right]$} & {$[\mathrm{mm}]$} & {$[\mathrm{mm}]$} & {$[\mathrm{mm}]$} & {$[\mathrm{mm}]$} & {$\left[10^{6} \mathrm{~m}^{3}\right]$} & {$\left[\mathrm{m}^{3} / \mathrm{s}\right]$} & {$\left[\mathrm{l} / \mathrm{s} / \mathrm{km}^{2}\right]$} & {$\left[10^{6} \mathrm{~m}^{3}\right]$} & {$[-]$} \\
\hline 0.86 & 36.5 & \multirow{3}{*}{710} & 388 & 323 & -1 & -0.052 & \multirow{3}{*}{0.374} & 10.2 & 11.8 & 0.46 \\
\hline 0.87 & 37.8 & & 400 & 311 & -1 & -0.045 & & 9.9 & 11.8 & 0.44 \\
\hline 0.88 & 39.4 & & 412 & 299 & -1 & -0.049 & & 9.5 & 11.8 & 0.42 \\
\hline
\end{tabular}

\section{DYNAMIC VOLUME}

Using estimated monthly volumes we obtain the dynamic volume $(\Delta \mathrm{V})$ as the difference between the maximum $\left(\mathrm{V}_{\max }\right)$ and minimum $\left(\mathrm{V}_{\min }\right)$ volume of water in the karst aquifer in the reference period, as shown in Fig. 9. 


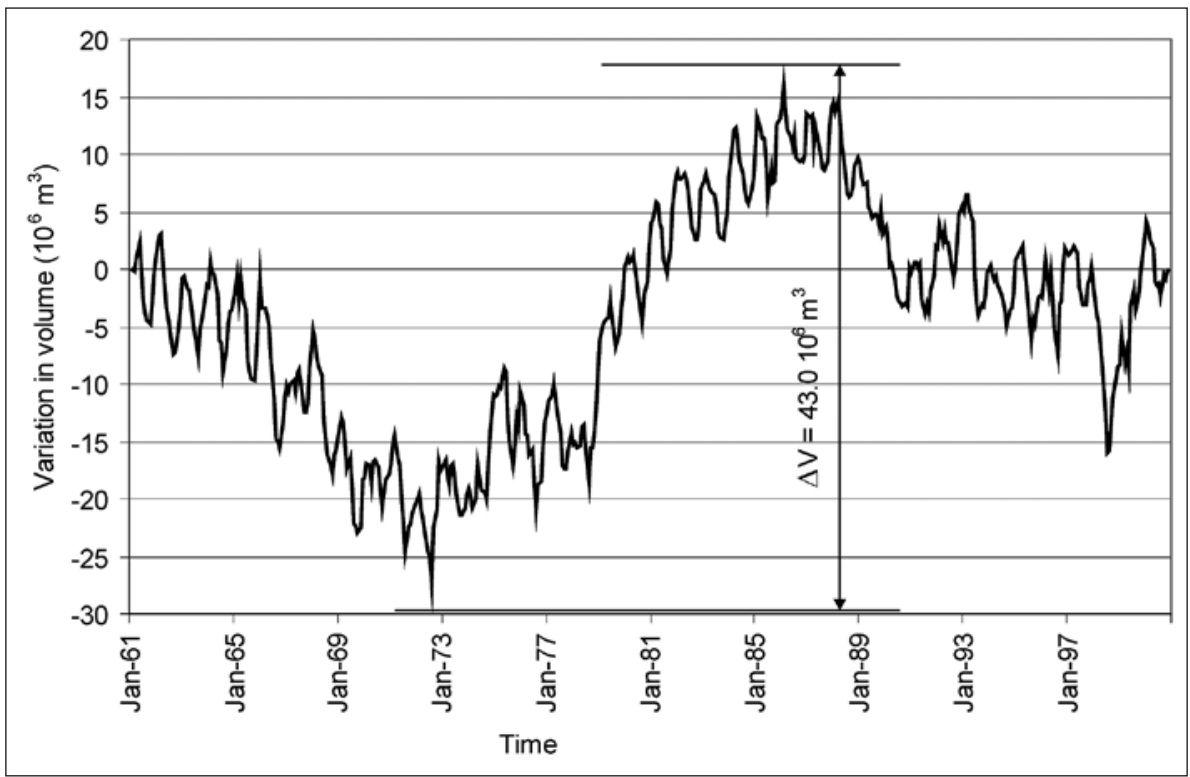

Fig. 9: Estimated Grza karstic aquifer catchment dynamic volume of water in the reference period.

\section{DISCUSSION}

Two ranges for Grza spring catchment area have been reported in the recent studies: 30 to $50 \mathrm{~km}^{2}$ (Jemcov 2007) and 36.6 to $43.6 \mathrm{~km}^{2}$ (Ristić 2007), smaller areas for dry and larger for wet years. As an average catchment area, our estimate is within the ranges.

There are three distinct sections on the obtained plot $\Theta=f(F)$ (Fig. 8). For $\Theta$ values up to 0.5 , that correspond to $23 \mathrm{~km}^{2}<F<27 \mathrm{~km}^{2}$, the dependence between $\Theta$ and $\mathrm{F}$ is approximately linear, as well as for $\Theta>0.96$ and $F>70 \mathrm{~km}^{2}$. The central part of the plot is obviously nonlinear. According to the model results, the average size of the catchment area in the reference period is at the inflection point of nonlinear plot section, where $\Delta F / \Delta \Theta$ is approximately the same in two neighbouring segments of the plot. Here, it is $1.3 / 0.01$ compared to $1.6 / 0.01$ according to the data shown in Table 3. This ratio also illustrates model accuracy for F estimate, when $\Theta$ is estimated with precision of 0.01 . It also reflects to $V_{0}-V_{K}$ approximation of $10^{4} \mathrm{~m}^{3}$ in the reference period.
Mean evapotranspiration relative to precipitation in the reference period is $56 \%$. It is in the range of 45 to $60 \%$ given as realistic evapotranspiration from karst regions in Serbia (Stevanović 1991; 2010, Jemcov \& Petrič, 2009).

Although we obtained satisfactory results for evapotranspiration in the reference period, the Thornthwaite method application should be re-examined. It is found that Thornthwaite estimates

correlated well with the mean annual and peak monthly Penman-Monteith estimates for six weather stations in Serbia, but significantly underpredicted mean daily PET in the first half of the year and overpredicted it in the second half (Trajković, 2005). For 40 years reference period, these differences possibly levelled and we obtained good result.

\section{CONCLUSION}

Presented methodology yielded good results for presented case, taking into account a complex problematics of catchment area quantification for karstic aquifers. For the time being, it is a graphoanalytical method. Upon the first run of water balance in the reference period, the probable catchment area and rough estimate of model parameter are acquired from the plot $\Theta=f(F)$, and subsequently $\Theta$ and $F$ are calculated in local search by opti- 
mization for a range of values in the naighbourhood of rough estimates.

Since the model is based on water balance equation, it holds potential to resolve three key unknowns in the analysis of karst aquifers: (1) the size of the active catchment area from which the water flows to and is stored in the karst aquifer for many years, (2) estimate real evapotranspiration, and (3) obtain the size of the dynamic volume of the underground reservoir.

In the current form, model has been applied on 15 explored karst springs in Serbia. Results obtained for all studied karst springs follow parameters obtained from exploration data, and catchment area stands out as the the best model output. The worst estimate of catchment area differs $20 \%$ from detailed hydrogeological and speleological investigation results. However, model has two major weaknesses: lack of analytical form, particularly for $\Theta=f(F)$, and application of the Thornthwhite method for RET estimation. These weaknesses need to be resolved together.
In the future investigations we will concentrate on different methods for PET and RET estimation, especcialy those that do not require numerous input data that are not available at many weather stations. Instead of point precipitation data, we will use arial precipitation estimates, wherever raingauge records have acceptable record lengths and data gaps that could be filled. With more reliable precipitation input and estimates of RET, we would try to obtain analytical form for nonlinear section of $\Theta=f(F)$ relation, and its inflection point that would yield direct solution of model parameter and catchment area value. There are also indications that nonlinear section of $\Theta=f(F)$ points out to the range of catchment area in the reference period.

Despite the lack of a theoretical foundation for model parameter $\mathrm{Q}$, this method makes it possible to obtain values of karst aquifier catchment area that are approximately correct to serve as an indicator of water balance in the likely situation when area is not explored enough, and meteorological data are limited to precipitation and temperature only.

\section{ACKNOWLEDGEMENT}

The research presented in the paper is funded from the Republic of Serbia Ministry of Education and Science resources within scientific project no. 37005 'Assessment of Climate Change Impact on Serbian Water Resources'. We would like to thank the personnel of the Hydro-Mete- orological Service of Republic of Serbia and the Paracin Public Utility Company for providing the data required for this research, and to three anonymous reviewers for their comments and suggestions that significantly improved the paper.

\section{REFERENCES}

Bakalowicz, M., 2005: Karst groundwater: a challenge for new resources.- Hydrogeology Journal 13 (1), 148-160.

Bonacci, O., 1987: Karst hydrology, with special reference to the Dinaric karst.- Springer Verlag. pp. 184, Berlin, Heidelberg.

Bonacci, O., Magdalenić, A., 1993.: The catchment area of the Sv. Ivan Karst spring in Istra (Croatia).- Ground Water, 31(5), 767-773.

Bonacci, O., 1999: Water Circulation in Karst and Determination of Catchment Areas: Example of the River Zrmanja.- Hydrological Sciences - Journal - des Sciences Hydrologiques, 44(3), 373-386.
Bonacci, O., Jukić, D., \& I. Ljubenkov, 2006: Definition of catchment area in karst: case of the river $\mathrm{Krcic}$ and Krka, Croatia.- Hydrological Sciences - Journal - des Sciences Hydrologiques, 51(4), 682-699.

Cvijić, J., 1895: Caves and Underground Hydrography of Eastern Serbia.- Voice of the Serbian Royal Academy, Belgrade, 1-101 (printed in Serbian).

Dragišić, V., Miladinović, B., Vukičević, R. \& S. Grbović, 1990: Some New Results of Aquifer Flow Tracing in Eastern Serbian Karst.- Serbian Geological Society Proceedings for year 1990, Belgrade, 119-125, (printed in Serbian). 
Djurović, P., 1998: Speleological Atlas of Serbia.- Serbian Academy of Sciences and Arts, Jovan Cvijic Geographical Institute, Serbian Nature Conservation Institute, University of Belgrade, Faculties of Geography and Biology, special editions, Volume 52, Belgrade, pp. 328, (printed in Serbian).

Ford, D.C., Williams, P.W., 2007: Karst hydrogeology and geomorphology.- Wiley, Chichester, USA, pp. 578.

Fiorillo, F., Doglioni, A., 2010: The relations between karst spring discharge and rainfall by cross-correlation analysis (Campania, southern Italy).- Hydrogeology Journal, Vol 18 (8), 1881-1895.

Goldscheider, N., Meiman, J. \& C. Smart, 2008: Tracer tests in karst hydrogeology and speleology.- International Journal of Speleology 37 (1), 27-40.

Jemcov, I., 2007: Water supply potential and optimal exploration capacity of karst aquifer system.- Environmental Geology, Vol. 51 (5), 767-773.

Jemcov, I., Petrič M., 2009: Measured precipitation vs. effective infiltration and their influence on the assessment of karst systems based on results of the time series analysis.- Journal of Hydrology 379, 304-314.

Krešić, N., 1988: Yugoslav Karst and Caves - Science Books, Belgrade, pp. 149, (printed in Serbian).

Marković, J., 1954: Relief of Crnica and Grza catchment area.- Geographic institute "Jovan Cvijić" of the Serbian Academy of sciences and arts, 19-83 (printed in Serbian).

Milojević, N., 1975: Hydrogeology of the Grze Spring. Faculty of Mining and Geology Proceedings, Volume 18, 117-137, Belgrade, (printed in Serbian).

Petrič, M., 2002: Characteristics of recharge-discharge relations in karst aquifer, Institut za raziskovanje krasa ZRC SAZU, Založba ZRC, Postojna-Ljubljana.
Petrič, M., 2002: Characteristics of recharge-discharge relations in karst aquifer.- Založba ZRC, pp. 154, Postojna-Ljubljana.

Ravbar N., Engelhardt I. \& N. Goldscheider, 2011: Anomalous behaviour of specific electrical conductivity at a karst spring induced by variable catchment boundaries: the case of the Podstenjšek spring.- Slovenia. Hydrological Processes, Vol 25 (13), 2130-2140.

Ristić, V., 2007: Development of Simulation Model for Estimation of Karst Spring Daily Discharges - PhD Thesis. University of Belgrade, Faculty of Mining and Geology, Belgrade, pp. 319 (printed in Serbian).

Stevanović, Z., 1991: Hydrogeology of the Carpatho-Balkanide Karst in Eastern Serbia and its Water Supply Potential.- University of Belgrade, Faculty of Mining and Geology, Belgrade, pp. 245, (printed in Serbian).

Stevanović, Z., Milanović, S. \& V. Ristić Vakanjac, 2010: Supportive Methods for Assessing Effective Porosity and Regulating Karst Aquifes, Acta Carsologica, Slovenia, ISSN 0583-6050, Volume 39, number 2, 301-312.

Thornthwaite C. W., 1948: An Approach to a Rational Classification of Climates, Geographical Review, Vol. 38, No. 1, 55-94.

Trajković S., 2005: Temperature-Based Approaches for Estimating Reference Evapotranspiration.- Journal of Irrigation and Drainage Engineering, Vol. 131, No. 4, July/August 2005, 316-323.

White W., 2002: Karst hydrology: recent developments and open questions, Engineering Geology 65 (2002), 85-105. 